Jurnal Pemberdayaan: Publikasi Hasil Pengabdian kepada Masyarakat

Vol. 4, No. 3, Desember 2020, Hal. 297-304

ISSN: 2580-2569; e-ISSN: 2656-0542

DOI: https://doi.org/10.12928/jp.v4i3.1951

\title{
Pemanfaatan Teknologi Tepat Guna pada Usaha Produksi Bumbu Bubuk Instan "Meurasa" Masakan Khas Aceh
}

\author{
Yuliani Aisyah, Raida Agustina, Dewi Yunita \\ Fakultas Pertanian, Universitas Syiah Kuala, Jl. Tgk. Hasan Krueng Kalee No. 3, Banda Aceh \\ Email: yuliani.aisyah@unsyiah.ac.id
}

\begin{abstract}
ABSTRAK
Provinsi Aceh merupakah salah satu daerah yang terkenal dengan berbagai jenis masakan tradisional yang sangat banyak menggunakan rempah-rempah dan bumbu dasar. Jenis masakan Aceh yang sudah sangat terkenal antara lain Mie Aceh, Nasi Goreng Aceh, Kari Aceh, Ayam Tangkap Aceh dan lain-lain. Mitra dalam kegiatan ini adalah unit usaha yang memproduksi bumbu bubuk instan "Meurasa" masakan khas Aceh. Permasalahan utama didalam memproduksi bumbu bubuk instan adalah pada proses pengeringan bahan bumbu, penggilingan, dan pengemasan bumbu. Tujuan kegiatan pengabdian kepada masyarakat ini adalah mengintroduksi beberapa teknologi yaitu berupa alat pengering tenaga surya dengan solar cell, mesin penggiling (grinder machine) dan mesin pengemas (sealer machine). Metode yang digunakan dalam kegiatan ini mencakup beberapa metode yaitu penyuluhan, pelatihan, dan demonstrasi. Hasil pelaksanan kegiatan pengabdian kepada masyarakat antara lain telah terjadi peningkatan pengetahuan dan pemahaman tentang alat pengering, mesin penggiling bumbu (grinder machine), dan mesin pengemas (sealer machine) pada mitra, telah dapat memperbaiki mutu produk, daan terjadi peningkatan jumlah produk yang dihasilkan sekaligus dapat memperluas pemasaran dengan peningkatan jumlah produk yang disuplai ke outlet-outlet dan swalayan.
\end{abstract}

Kata kunci: Bumbu bubuk instan, rempah-rempah, pengering solar cell, higienis

\begin{abstract}
Aceh Province is one of the regions which is famous for various types of traditional cuisine which very much uses spices and basic herbs. The types of Acehnese dishes that are already very well-known include mie Aceh, nasi goreng Aceh, kari Aceh, ayam tangkap Aceh, and others. Partners in this activity are home industry that produce instant seasoning powder "Meurasa" specialties from Aceh. The main problem in producing instant powder seasonings is the process of drying seasoning ingredients, milling, and packaging of seasonings. The purpose of this community service activity is to introduce several technologies, namely in the form of solar dryers with solar cells, grinder machines and sealer machines. The method used in this activity includes several methods, namely counseling, training, and demonstration. The results of community service activities include increasing knowledge and understanding of dryers, grinder machines, and sealer machines for partners, which have been able to improve product quality, and there has been an increase in the number of products produced at once can expand marketing by increasing the number of products supplied to outlets and supermarkets.
\end{abstract}

Keywords: Instant Seasoning Powder, Spices, Solar Cell Dryers, Hygienic

\section{PENDAHULUAN}

Indonesia memiliki rempah-rempah yang berlimpah. Umumnya rempah-rempah digunakan sebagai bumbu pada masakan. Penambahan rempah-rempah berfungsi untuk meningkatkan cita rasa dan pengawet makanan. Cita rasa yang dihasilkan dapat berupa aroma dan rasa yang sedap. Istilah lain bumbu dikenal juga sebagai seasoning. Seasoning banyak dijumpai berbentuk bubuk. Kelebihan dari pada bentuk bubuk adalah memiliki nilai ekonomis yang tinggi karena memudahkan pengemasan dan pengangkutannya. 
Bumbu masak merupakan penggabungan rempah-rempah dan bumbu dasar seperti bawang putih, bawang merah dan garam yang ditambahkan pada bahan makanan sebelum disajikan. Penggunaan bumbu dapat meningkatkan tingkat penerimaan konsumen karena bumbu dapat meningkatkan cita rasa alami dari bahan pangan, sehingga bumbu yang dicampurkan ke dalam masakan akan menimbulkan efek selera dan memberikan ciri khas tersendiri pada masakan (Adawyah, 2011). Menurut (Haryati, 2015), bumbu berfungsi untuk meningkatkan cita rasa pada makanan dan juga dapat digunakan sebagai bahan pengawet pada makanan. Cita rasa yang diberikan oleh bumbu seperti bau yang harum dan sangat sedap dapat menyenangkan sehingga dapat memberikan karakteristik pada bahan pangan.

Bumbu instan merupakan campuran dari berbagai rempah-rempah dengan komposisi tertentu dan dapat langsung digunakan sebagai bumbu masak untuk masakan tertentu. Jenis bumbu instan ada dua, yaitu bumbu instan kering dan basah. Bumbu instan kering berbentuk bubuk, sedangkan bumbu instan basah dalam bentuk pasta. Bumbu instan yang berasal dari rempah-rempah yang diformulasikan dapat dimanfaatkan untuk konsumsi rumah tangga sehari-hari ataupun industri (Sianipar, 2008).

Provinsi Aceh merupakah salah satu daerah yang terkenal dengan berbagai jenis masakan khasnya, yang sangat banyak menggunakan rempah-rempah dan bumbu dasar. Jenis masakan Aceh yang sudah sangat terkenal antara lain Mie Aceh, Nasi Goreng Aceh, Kari Aceh, Ayam Tangkap Aceh dan lain-lain. Mitra pelaksanaan Program Kemitraan Masyarakat (PKM) adalah kelompok usaha produksi usaha Bumbu Bubuk Instan "Meurasa" di Desa Deyah Glumpang Kecamatan Meuraxa Kota Banda Aceh. Bumbu bubuk instan "Meurasa" memproduksi beberapa jenis bumbu masakan khas Aceh, seperti Mie Aceh, Kari Aceh, Nasi Goreng Aceh, Masak Mirah, Ayam Tangkap dan Masak Puteh. Usaha ini milik bapak Edi Sandra yang telah ditekuninya sejak tahun 2014. Usaha ini telah memiliki 6 (enam) orang pekerja (karyawan). Sebagian bahan-bahan baku untuk pembuatan bumbu bubuk instan dibeli dari petani setempat dan pasar-pasar tradisional. Saat ini kapasitas produksi bumbu bubuk instan "Meurasa" ratarata sebanyak 5.000 sachet/bulan, dengan berat tiap sachet adalah 20 gram. Proses pembuatan bumbu bubuk instan "Meurasa" meliputi pengirisan, pemblansiran, penggilingan, pemasakan/pemanasan, pengeringan, penepungan dan pengemasan.

Permasalahan utama didalam memproduksi bumbu bubuk instan "Meurasa" adalah pengeringan bahan, penggilingan, dan pengemasan bumbu. Permasalahan pertama yaitu proses pengeringan, selama ini proses pengeringan bahan yang dilakukan masih secara konvensional, yaitu dengan menggunakan sinar matahari. Meskipun metoda pengeringan dengan cara tradisional ini praktis, tidak memerlukan investasi biaya, namun memiliki beberapa kelemahan, terutama adalah bahan tidak sama keringnya sehingga kadar air dari bahan tidak akan sama dan waktu pengeringan tidak pasti (lama) karena sangat tergantung dari keadaan cuaca. Cuaca yang tidak baik mengakibatkan proses pengeringan menjadi lambat dan bisa saja bahan menjadi berjamur dan bau. Jika pada musim hujan maka usaha ini tidak bisa berproduksi. Permasalahan kedua adalah kapasitas alat penggilingan yang dimiliki masih kecil sehingga bumbu bubuk yang dihasilkan terbatas, sehingga sulit untuk menambah kapasitas produksi jika pemesanan bumbu meningkat. Demikian juga untuk proses pengemasan, masih menggunakan alat hand sealer dengan kapasitas kecil, sehingga juga akan sulit untuk menambah kapasitas produksi jika pemesanan bumbu meningkat.

Saat ini, banyak metode atau teknologi alat pengering telah dikembangkan dan diaplikasikan untuk produk pangan, diantaranya teknologi pengering unggun terfluidisasi (Adi dkk., 2013), alat pengering tipe rak dengan energi surya, biomassa, dan kombinasi (Panggabean dkk., 2017), alat pengering tipe rak sistem double blower (Rahbini dkk., 2016), oven, spray dryer dan microwave dryer (Fadhilah dkk., 2010), alat pengering klanting tipe rak dengan sumber panas kompor listrik (Hardanto \& Sulistyo, 2010), alat pengering tipe rak menggunakan kolektor surya (Sophyan, 2016), alat pengering tenaga surya sistem bongkar 
pasang ((Bintang dkk., 2013), dan alat pengering solar cell berbasis mikrokontroler atmega8 (Purba, 2018).

Pemanfaatan alat pengering untuk menunjang home industri yang pada umumnya berskala kecil, selalu memerlukan tersedianya energi panas. Energi panas ini mutlak diperlukan, karena sekitar $70 \%$ biaya operasi pengeringan digunakan untuk konsumsi energi panas atau bahan bakar. Untuk menghemat bahan bakar mulai dikembangkan alat pengering tenaga surya. Secara umum, keuntungan pengeringan secara mekanis dengan energi surya dibanding dengan cara dijemur langsung (alami) adalah, pengeringan mekanis mempunyai efisiensi dan efektifitas yang lebih tinggi, serta terhindar dari kontaminasi debu dan kotoran yang lain ((Siswantoro., 2003).

Dengan memanfaatkan unit usaha yang sudah ada, potensi ketersediaan bahan baku, dan sumber daya manusianya, maka mitra bumbu bubuk instan "Meurasa" ini sangat berpotensi untuk dikembangkan menjadi kelompok masyarakat yang memproduksi pangan secara mandiri, sehingga sangatlah tepat jika diadakan suatu kegiatan Program Kemitraan Masyarakat (PKM) untuk mengintroduksi teknologi tepat guna berupa aplikasi alat/mesin pengolahan, khususnya alat pengering tenaga surya dengan solar cell. Kegiatan PKM ini bertujuan untuk mengatasi permasalahan mitra sehingga dapat meningkatkan produktivitas mitra dan nilai tambah produk, serta mengembangkan unit usaha masyarakat yang mandiri secara ekonomis.

\section{METODE}

Pengabdian dilaksanakan pada salah satu pelaku usaha pegasapan kelompok usaha produksi usaha Bumbu Bubuk Instan "Meurasa" di Desa Deyah Glumpang Kecamatan Meuraxa Kota Banda Aceh, yang berjarak sekitar $\pm 15 \mathrm{~km}$ atau sekitar 30 menit perjalanan darat dari Univeristas Syiah Kuala. Pengabdian ini dilaksanakan pada bulan Juni sampai Bulan September 2019 dengan melibatkan 2 orang mahasiswa tingkat akhir Program Studi Teknologi Hasil Pertanian. Metode yang digunakan dalam kegiatan ini mencakup beberapa metode sebagai berikut:

1. Metode penyuluhan, digunakan untuk memperkenalkan prinsip alat pengering tenaga surya dengan solar cell, mesin penggiling bumbu kering (grinder machine), dan mesin pengemas (sealer machine)

2. Metode pelatihan dan demonstrasi, digunakan untuk melatih mitra dalam menggunakan alat pengering mesin penggiling bumbu kering (grinder machine), dan mesin pengemas (sealer machine)

Tahapan kegiatan yang dilakukan untuk menyelesaikan permasalahan di mitra adalalah sebagai berikut:

1. Persiapan awal

2. Pengadaan peralatan

3. Penyuluhan dan demonstrasi alat/mesin

Partisipasi mitra dalam kegiatan ini adalah sebagai peserta dalam semua kegiatan yang dilakukan, mendukung dan bekerjasama dengan tim pengabdi untuk lancarnya pelaksanaan kegiatan. Mitra juga menyediakan lokasi tempat kegiatan penyuluhan, pelatihan, dan demonstrasi alat dan mesin produksi. Selain itu, mitra juga berkomitmen untuk memanfaatkan dan menjaga dengan baik alat dan mesin produksi yang diberikan untuk pengembangan dan keberlangsungan usaha mitra.

Evaluasi dilakukan pada setiap tahap kegiatan, baik kegiatan penyuluhan, kegiatan pelatihan maupun kegiatan demonstrasi. Evaluasi yang dilakukan mencakup pemahaman mitra pada saat penyuluhan, keterampilan menggunakan alat dan mesin yang diberikan. kontinuitas pemakaian alat dan keuntungan/efisiensi penggunaan alat dan mesin dalam proses produksi. 
Evaluasi dilakukan dengan pengisian daftar pertanyaan maupun dengan pengamatan atas variabel yang telah ditentukan. Dengan demikian dapat dilihat indikator akhir pencapaian target dari kegiatan pengabdian ini baik secara kualitatif maupun kuantitatif.

\section{HASIL, PEMBAHASAN, DAN DAMPAK Persiapan pelaksanaan pengabdian}

Pada tahap persiapan, tim pengabdi melakukan pertemuan dengan mitra untuk melakukan pemaparan dan sosialisasi program kegiatan, dan dilanjutkan dengan menyusun jadwal pelaksanaan kegiatan dan mendiskusikan kebutuhan yang diperlukan pada pelaksanaan pengabdian. Secara internal tim pengabdi juga mulai menyiapkan bahan, peralatan dan materi yang diperlukan dalam kegiatan penyuluhan, pelatihan dan demonstrasi. Kuisioner untuk diisi mitra juga disiapkan untuk keperluan evaluasi hasil kegiatan.

\section{Pelatihan dan demonstrasi penggunaan alat pengering energi surya dengan solar cell}

Teknologi yang diperkenalkan oleh tim pengabdi adalah berupa alat pengering energi surya dengan solar cell. Pelatihan diawali dengan menyampaikan penjelasan tujuan dan manfaat pelaksanaan pelatihan, prinsip kerja alat dan manual operasional cara menggunakan alat, dan demonstrasi penggunaan alat, seperti tampak pada Gambar 1. Beberapa hal yang sudah dirasakan oleh mitra setelah menggunakan alat pengering yang diberikan yaitu proses pengeringan lebih cepat, bahan lebih higienis, warna bahan lebih terang, dan pada saat proses penggilingan bahan atau pembubukan memerlukan waktu lebih cepat.
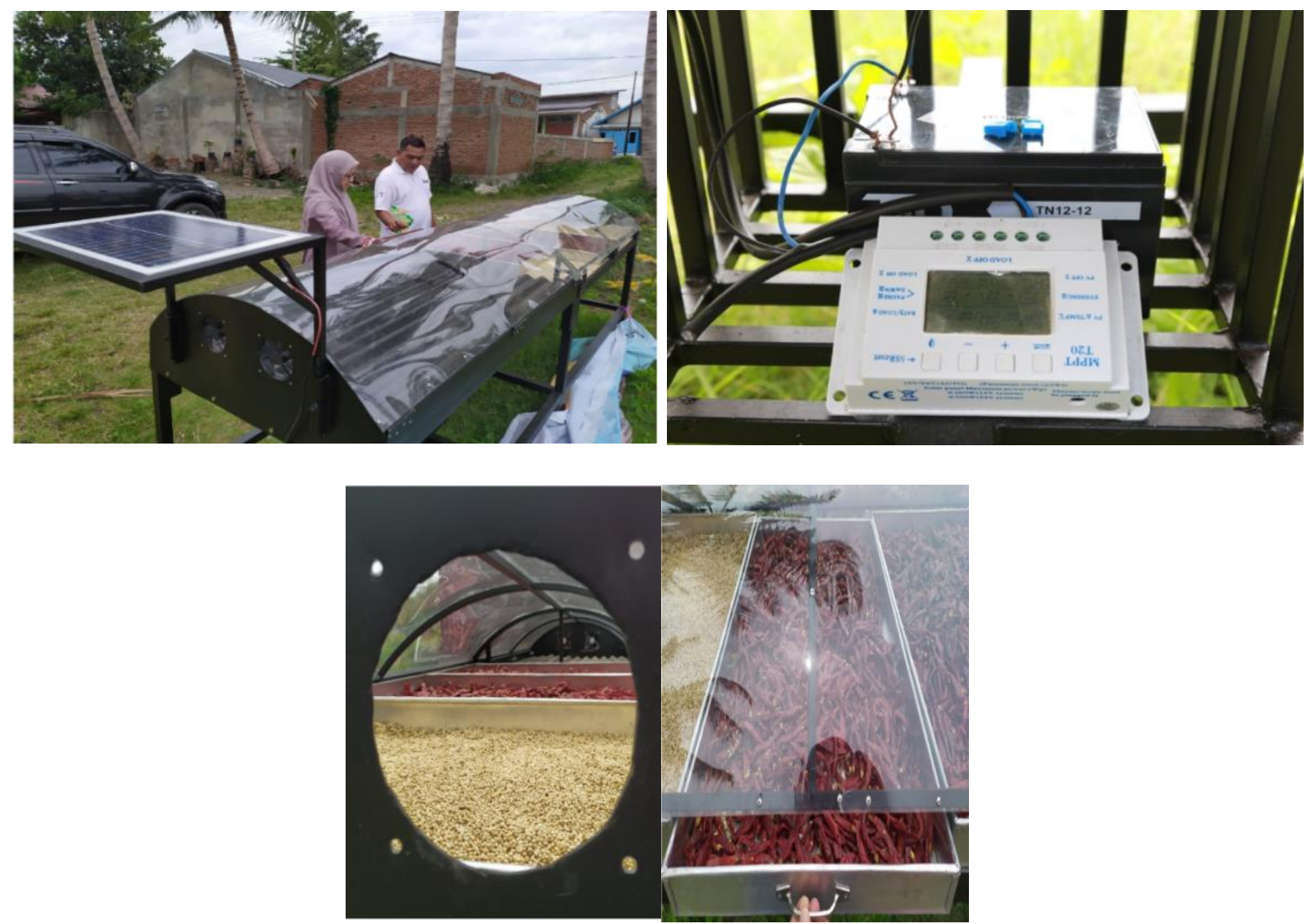

Gambar 1. Demonstrasi penggunaan alat pengering (kiri), Baterai yang digunakan untuk menyimpan energi panas matahari (kanan), dan Pengeringan cabe merah dan lada/merica

(bawah) 
Prinsip kerja dari alat pengering energi surya dengan solar cell adalah menggunakan prinsip efek rumah kaca dimana cahaya matahari yang menembus ke dalam ruang pengering dipantulkan kembali oleh benda di dalam ruang pengering, tetapi gelombang panas tersebut terperangkap di dalam ruang pengering sehingga tidak bercampur dengan udara dingin di luar ruang pengering sehingga suhu pada ruang pengering lebih tinggi dan lebih stabil daripada suhu lingkungan. Suhu didalam ruang pengering dapat berkisar antara 30-65 ${ }^{\circ} \mathrm{C}$. Kegunaan solar cell adalah menyerap energi panas matahari yang kemudian di simpan ke dalam baterai. Energi tersebut digunakan untuk menggerakkan kipas, yang berfungsi untuk mengalirkan udara dari absorber ke ruang pengering menuju outlet, sehingga mempercepat keluarnya uap air dari ruang pengering ke lingkungan, dan mempercepat pengeringan ((Al-Hasani., 2017).

Hasil uji coba menggunakan alat pengering ini menunjukkan waktu pengeringan lebih cepat (dari 5 hari menjadi 3 hari), dan warna produk yang dikeringkan (cabe merah, lada, ketumbar) menjadi lebih terang/cerah (Gambar 1). Bunga Mentari, dan Nurba (2017) menyatakan bahwa rata-rata suhu pada alat pengering energi 1 lebih tinggi dibandingkan suhu pada lingkungan, sehingga menyebabkan kelembaban relatif pada alat pengering lebih rendah dibandingkan pada lingkungan, sehingga susut bobot dan laju pengeringan pada pengeringan jahe merah menggunakan alat pengering ini lebih tinggi dibandingkan pada metode penjemuran. Kadar air jahe merah yang dikeringkan dengan menggunakan alat pengering signifikan lebih rendah dibandingkan kadar air pada jahe merah yang dikeringkan dengan metode penjemuran. Selain itu, pengeringan menggunakan alat pengering energi surya menghasilkan warna jahe merah yang lebih cerah dibandingkan pada penjemuran.

Karakteristik alat pengering tipe Hohenheim pada pengeringan Pliek- $u$ adalah suhu ratarata dalam alat pengering $55 \pm 9^{\circ} \mathrm{C}$, sedangkan suhu rata-rata lingkungan $35 \pm 1^{\circ} \mathrm{C}$. Kelembaban relatif dalam alat pengering adalah $39 \pm 13 \%$, sedangkan kelembaban relatif rata-rata lingkungan $62 \% \pm 4 \%$ (Rita dkk., 2015)

\section{Pelatihan dan demonstrasi penggunaan mesin penggiling bumbu kering (grinder machine)}

Mesin penggiling bumbu kering ini mempunyai dua buah piringan (terbuat dari baja), yang satu berputar (rotor) dan yang lainnya diam (stator). Mekanisme penghalusan terjadi dengan adanya gaya geseran antara permukaan bahan yang digiling dengan permukaan piringan dan sesama bahan yang digiling.

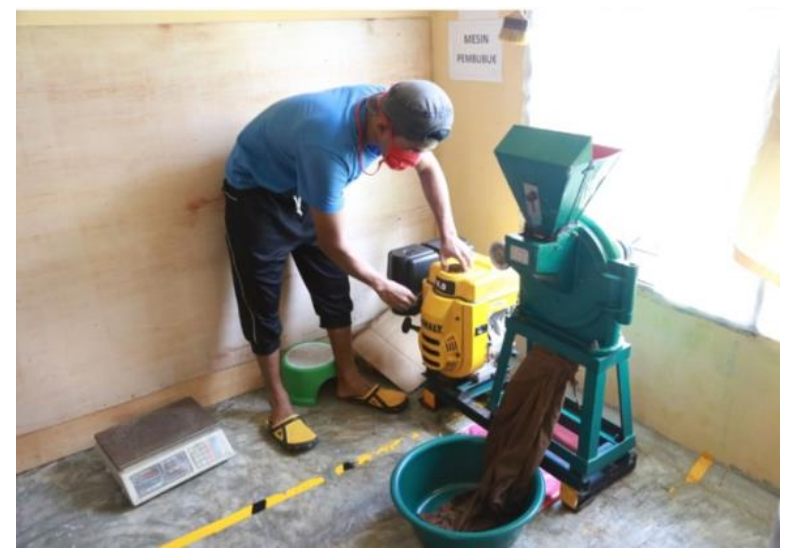

Gambar 2. Demonstrasi mesin penggiling bumbu kering

Hasil uji coba menggunakan mesin ini, menunjukkan bahwa hasil gilingan menjadi lebih halus, jumlah gilingan lebih banyak dan proses penggilingan lebih cepat (Gambar 2 dan 3). 


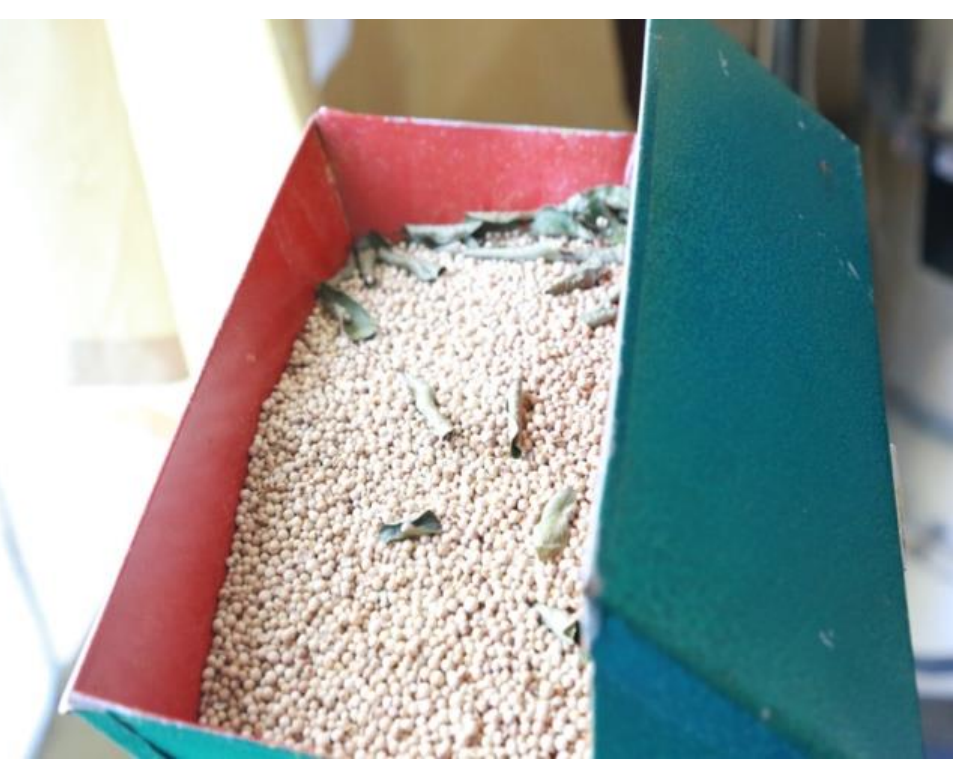

Gambar 3. Penggilingan lada/merica

\section{Pelatihan dan demonstrasi penggunaan mesin pengemas (sealer machine)}

Mesin sealer adalah mesin yang digunakan untuk mengemas kemasan yang menggunakan bahan seperti plastic maupun aluminium foil. Dengan adanya alat ini membantu mempercepat proses pengemasan. Hasil uji coba menggunakan mesin ini, hasil kemasan menjadi lebih bagus (tidak bocor), lebih mudah dalam penggunaan, dan proses pengemasan menjadi lebih cepat (Gambar 4).
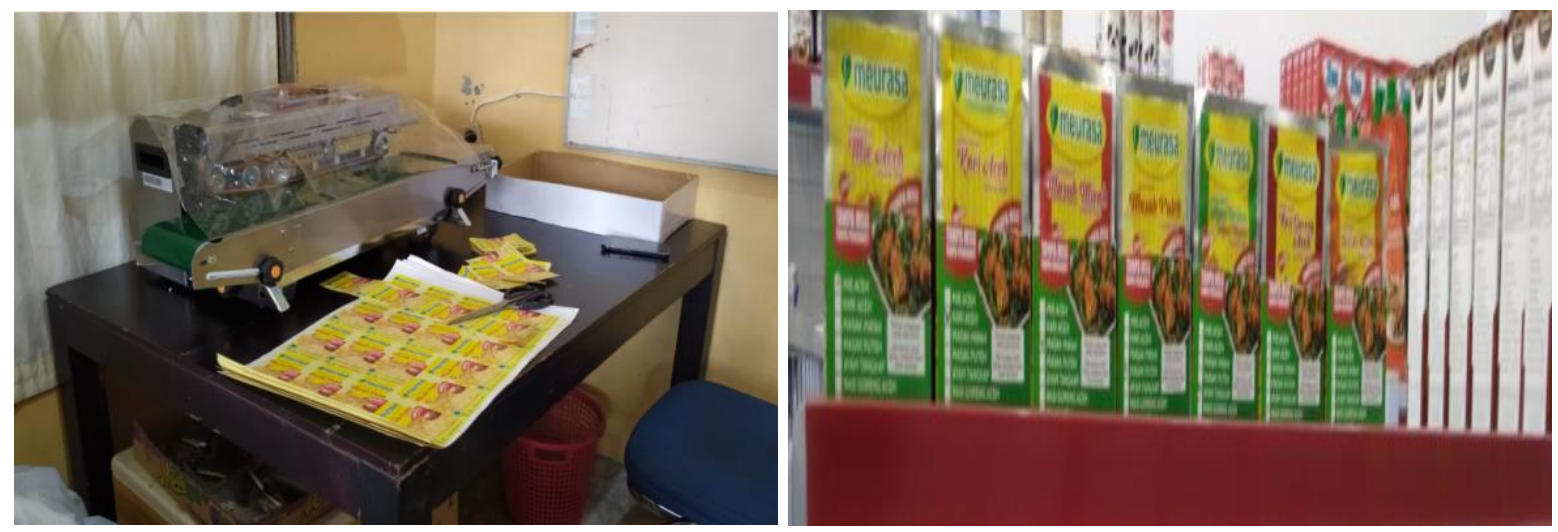

Gambar 4. Demonstrasi mesin sealer (kiri) dan Produk bumbu bubuk instan "Meurasa" dipasarkan di swalaya (kanan)

\section{SIMPULAN}

Pelaksanaan pengabdian kepada masyarakat telah meningkatkan pengetahuan dan pemahaman mitra tentang alat pengering, mesin penggiling bumbu (grinder machine), dan mesin pengemas (sealer machine) pada mitra, selain itu mitra pengabdian telah dapat menggunakan alat-alat yang diberikan sehingga dapat memperbaiki mutu dan pemasaran produk bumbu instan yang dihasilkan.

\section{UCAPAN TERIMAKASIH}

Penulis mengucapkan terima kasih kepada Direktorat Riset dan Pengabdian Masyarakat Direktorat Jenderal Penguatan Riset dan Pengembangan Kementerian Riset, Teknologi dan 
Pendidikan Tinggi yang telah memberi dukungan finansial pada Skema Program Kemitraan Masyarakat (PKM), sehingga terlaksananya kegiatan pengabdian ini, melalui Lembaga Penelitian dan Pengabdian Kepada Masyarakat Universitas Syiah Kuala Banda Aceh.

\section{DAFTAR PUSTAKA}

Adawyah, R. (2011). Pengolahan dan Pengawetan Ikan. Jakarta: Bumi Aksara.

Adi, R., Amalia, N., Suherman, \& Ratnawati. (2013). Penggunaan Teknologi Pengering Unggun Terfluidisasi Untuk Meningkatkan Efisiensi Pengeringan Tapioka. Jurnal Teknologi Kimia Dan Industri, 2(3), 37-42.

Al-Hasani, M., Zulfahrizal, \& Agustina, R. (2017). Kajian Variasi Ketebalan Tumpukan Fermentasi Terhadap Kualitas Pliek U dan Minyak Pliek Yang Dikeringkan Dengan Alat Pengering Tipe Hohenheim. Jurnal Ilmiah Mahasiswa Pertanian Unsyiah, 2(2), 386395.

Bintang, Y. M., Pongoh, J., \& Onibala, H. (2013). Konstruksi dan Kapasitas Alat Pengering Ikan Tenaga Surya Sistem Bongkar-Pasang. Media Teknologi Hasil Perikanan, 1(2), 4043. https://doi.org/10.35800/mthp.1.2.2013.1632

Bunga Mentari, Diswandi Nurba, R. K. (2017). Karakteristik Pengeringan Jahe Merah (Zingiber officinale var rubrum rhizome) dengan Metode Penjemuran dan Menggunakan Alat Pengering Tipe Hohenheim. 2(2), 439-448.

Fadhilah. (2010). Terhadap Kecepatan Pengeringan dan Kualitas Kareganan dari Eucheuma cottonii A dt. Rekaya Kimia Dan Proses, II(01), 4-5.

Hardanto, H., \& Sulistyo, S. (2010). Rancang Bangun Alat Pengering Klanting Tipe Rak dengan Sumber Panas Kompor Listrik. Jurnal Keteknikan Pertanian, 24(1), 21774.

Haryati. (2015). Rempah-Rempah Dan Bahan Penyegar. 1-41.

Panggabean, T., Triana, A. N., \& Hayati, A. (2017). Kinerja Pengeringan Gabah Menggunakan Alat Pengering Tipe Rak dengan Energi Drying Performance for Paddy Using Tray Dryer with Solar , Biomass , and Combination Energy. Agritech, 37(2), 229-235. Retrieved from doi: http://doi.org/10.22146/agritech.25989

Purba, E. (2018). Prototipe Pemanfaatan Solar Cell pada Pengeringan Biji Kopi Berbasis Mikrokontroler Atmega8.

Rahbini, Heryanto, Rachmat, B., \& Rhofita, E. I. (2016). Rancang Bangun Alat Pengering Tipe Rak Sistem Double Blower. Prosiding Sentia, 8(August), 6-10.

Rita K, R Agustina, R. (2015). Karakteristik Alat Pengering Tipe Hohenheim pada Pengeringan Pliek-u. Prosiding Seminar Nasional Badan Penelitian Dan Pengembangan Industri, 23-29.

Sianipar, D. (2008). Pendekatan Kadar Air Kritis.

Siswantoro, Margawiyanto, A., \& Masraukhi. (2003). 57 Rancang Bangun Alat Pengering Energi Surya Untuk Menunjang Agroindustri. 57-67.

Sophyan, N. F. (2016). Rancang Bangun Alat Pengering Ikan Tipe Rak Menggunakan Kolektor Surya. 
